Research Journal of Applied Sciences 7 (3): 158-164, 2012

ISSN: $1815-932 \mathrm{X}$

(C) Medwell Journals, 2012

\title{
Strain Partitioning and Dimensional Preferred Orientation in a syn-Tectonic Granitoid, S.E. Nigeria
}

\author{
Michael I. Oden \\ Department of Geology, University of Calabar, P.M.B. 1115, Calabar, Cross River, Nigeria
}

\begin{abstract}
Uwet granodiorite, a syn-tectonic granitoid of Pan-African age in South Eastern Nigeria is partly porphyritic, containing megacrysts of $\mathrm{K}$-feldspars, xenoliths and ellipsoidal bodies. The preferred orientations of the feldspar phenocrysts are in the NE-SW, NW-SE and N-S, the strongest being the NW-SE trend. The E-W sectors show minimum grain orientation. Calculated values of strain-arithmetic mean $\bar{R}$, geometric mean $G$ and harmonic mean $\mathrm{H}$ show minimum strain for grains in $\mathrm{E}-\mathrm{W}$ orientation and maximum strain for grains in N-S orientation. Phenocrysts in NE-SW and NW-SE orientations showed intermediate values of strain with the latter axis having higher values than the former. Generally, irrespective of orientation or axis, the relationship $\overline{\mathrm{R}}>\mathrm{G}>\mathrm{H}$ was found to hold. The analysis favours the interpretation that when two simple shears and a pure shear operate simultaneously in a viscous/ductile matrix at high temperature under a non-hydrostatic stress state, dimensional preferred orientation and strain are partitioned unequally along those axes. The paucity of phenocryst orientation and low strain values in the $\mathrm{E}-\mathrm{W}$ axis are an indication that maximum compressive stress $\left(\sigma_{1}\right)$ was oriented in this direction, during the Orogeny.
\end{abstract}

Key words: Strain, phenocrysts, orientation, arithmetic, geometric, harmonic

\section{INTRODUCTION}

Dimensional preferred orientation of rigid particles in a viscous matrix is a subject that has received much attention either by way of theoretical treatment alone, a combination of both theoretical treatment and computer modeling or yet still a combination of theoretical treatment, computer modeling and presentation of supporting natural geological evidence. Prominent among publications on this subject is the research of Masuda et al. (1995). Through a rigorous theoretical treatment based on the hydrodynamic equations of Ghosh and Ramberg (1976) combined with computer modeling, Masuda (op. cit) obtained several patterns of preferred orientation for different combinations of simultaneous pure shear and simple shear. Finally, they compared preferred orientation and ellipticity patterns occurring naturally in two mylonites in Japan, to their computer models and they noticed interesting similarities in the patterns. This enabled them to conclude that deformation within the two mylonites contains a simple shear component on which a certain amount of pure shear component is superimposed.

Ghosh and Ramberg (1976)'s treatment of the subject of dimensional preferred orientation was both at the theoretical and experimental levels. Their theoretical treatment was based on the equations of Jeffrey (1922) and Muskhelishvili (1953) for simple shear and pure shear, respectively. The model experiments, on the other hand were performed only for simple shear using silicone putty in which were embedded rigid rectangular blocks and linear inclusions. Their experiments did prove that Jeffery (1922)'s equation for rigid ellipsoidal bodies was also applicable to rigid rectangular blocks. They also showed, among other things that an elongate inclusion has the maximum rate of rotation when it is at a right angle to the simple shear direction and a minimum rate when it is parallel to the shear direction. Equant inclusions were also shown to have a constant rate of rotation while passive marker lines as well as very long rigid inclusions were shown to have no rotation when they are parallel to the direction of simple shear (Ghosh and Ramberg, 1976). This last observation appears as a sub-set of one of the later observations of Ghosh (1993) who showed that depending on the kinematical vorticity number and the aspect ratio $\mathrm{R}$ of ellipsoidal inclusions, they would rotate in all orientations when $\mathrm{R}$ is below a certain critical value. For values of $\mathrm{R}$ equal to or above the critical, the inclusions cannot rotate indefinitely because there is a stable orientation at which their rotations cease.

Reed and Tryggvason (1974) presented a study of computer-simulated dimensional fabric development in pure shear and simple shear deformation, without recourse to any real geologic case studies. They showed from their simulations that whether in simple shear or pure shear, the higher the strain ratio $\left(\lambda_{1} / \lambda_{2}\right)$, the better is the 
resulting fabric. Also their patterns for simple shear and pure shear were quite different even for the same strain ratios. All studies of dimensional preferred orientation in viscous media tend to confirm the view of Passchier (1987) that populations of rigid objects in rocks that have undergone ductile deformation, store a good amount of information. Such information can provide a better understanding of the physical behaviour of both the rigid particles as well as the viscous media surrounding them.

In this study, the orientations of rectangular tablets of feldspar phenocrysts in a syn-tectonic (pan-African) granitoid-Uwet granodiorite are presented. The orientations subdivide into pure shear and simple shear configurations and estimates of strain are made for each of the trends. Some of the conclusions arrived at emphasize the views of Ball (1980) and Rahaman et al. (1988) that an E-W compression operated throughout most of the pan-African orogeny.

\section{MACROSCOPIC ANALYSIS}

The most dominant intrusive rock type in the Western part of the Precambrian Oban Massif in S.E. Nigeria is the syn-tectonic granitoid-Uwet granodiorite.
This is largely a porphyritic, sometimes nonporphyritic granodiorite (Fig. 1) which has yielded a panAfrican age of $617 \pm 2$ ma from radiometric dating (Ekwueme and Nganje, 2000). Raeburn (1927) mapped this rock as porphyritic biotite gneissose granite but Rahman et al. (1981), Odigi (1986) and Ekwueme (1987, 1990) all recognize this unfoliated granitoid as a granodiorite. The porphyritic variety of this gray-coloured rock occurs in such areas as Igbofia Camp, Uyanga, Akwa Ibami and Ojor Nkonemba (Fig. 1) while the nonporphyritic variety is found mostly around Iwuru Obiotan, Nde Okoro and Agbangana.

Both varieties contain a lot of xenoliths of schist and meladiorite, the parent rocks of which were most probably in place prior to the intrusion of the granodiorite. In situ (non-xenolith) varieties of the meladiorite and schist are highly deformed, containing foliations of low to high angle dips. The area has a high density of pegmatite, quartz and aplite veins with small occurrences of anatectic gneiss and greenish charnockite near Uyanga and Iwuru Turunkekpen, respectively. Dolerite occurs in dykes of various sizes intruded into the granodiorite, mostly while late-stage fractures and faults are also visible in most of the rock types including the granodiorite (Fig. 2).

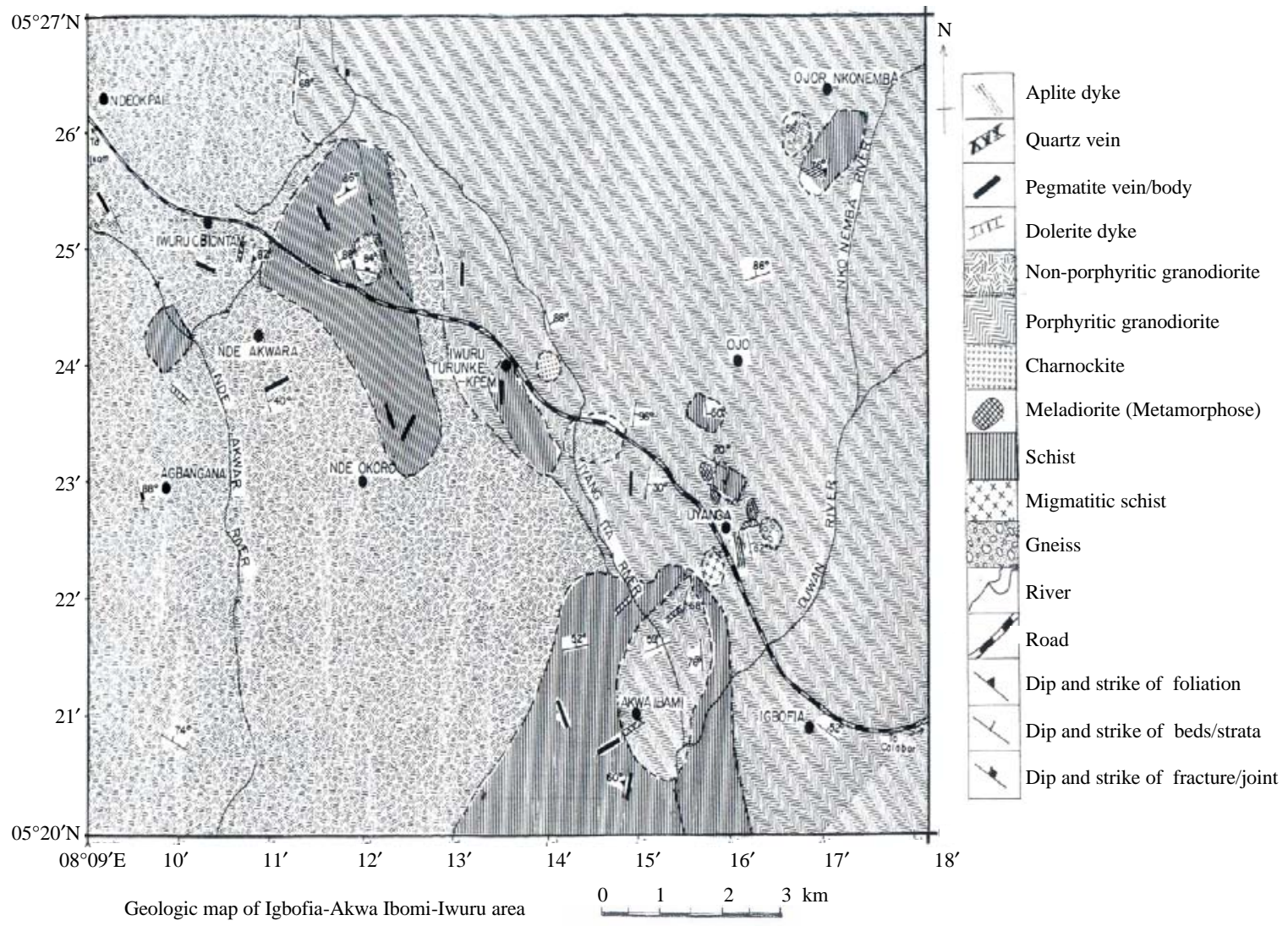

Fig. 1: The geologic map of Western Oban Massif 


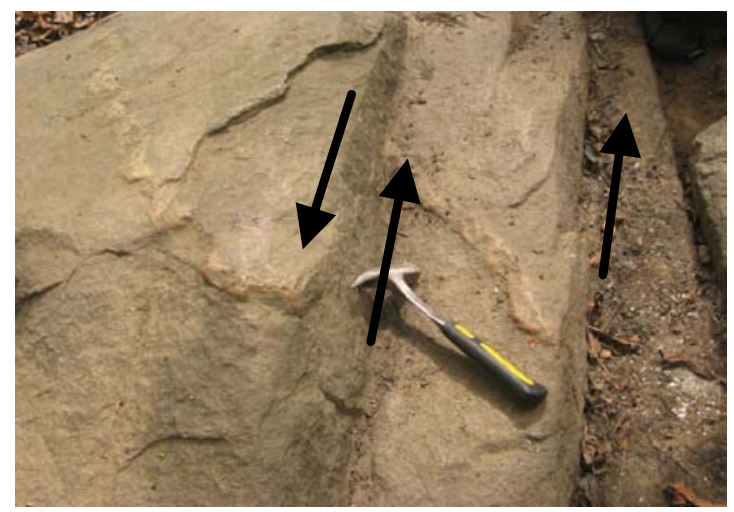

Fig. 2: Field exposure relationships of granodiorite, dolerite and faults

\section{MESOSCOPIC OBSERVATIONS}

At the level of the exposure and hand specimen, the porphyritic granodiorite is much more interesting than the non-porphyritic variety. Apart from xenoliths and ellipsoidal bodies (Fig. 3), the porphyritic granodiorite also incorporates feldspar phenocrysts of different sizes and orientations (Fig. 4 and 5). Sometimes, the phenocrysts are in such good alignment as to give a linear fabric to the rock but this preferred orientation tends to vary a little from place to place. For an analysis of the general preferred orientation and dimensional ratios of these grains, samples were randomly selected and measured from Igbofia, Akwa Ibami, Iwuru Central, Ojor and Iwuru Obiontan (Fig. 1).

\section{ANALYSIS OF DIMENSIONAL PREFERRED ORIENTATION}

Measurements of long axis orientation and length as well as short axis orientation and width were made for 249 feldspar phenocrysts within the map area. Grain lengths vary from $1.0-4.0 \mathrm{~cm}$ while grain widths vary from $0.4-2.8 \mathrm{~cm}$. A graph of major axis against minor axis of phenocrysts shows a good positive correlation (Fig. 6). This indicates that generally dimensional growth or shrinkage of the grains was constrained and correlated in such a way that any alteration (+ve or -ve) in the long axis was simultaneous with that in the short axis. Figure 6 is like Ramsay (1967)'s figure 5-8 as well as Ghosh (1993)'s figure 10:1. The straight line through the points as suggested by the computer is of the form:

$$
y=0.897 x+1.064
$$

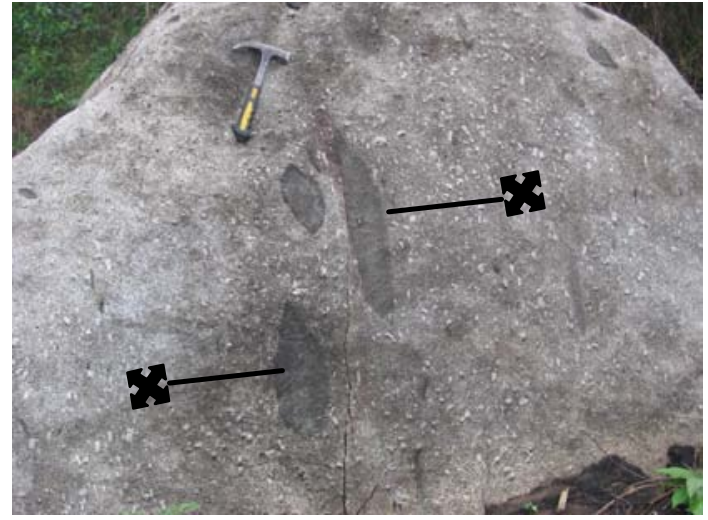

Fig. 3: Xenoliths (X) and ellipsoidal bodies are common in the granodiorite

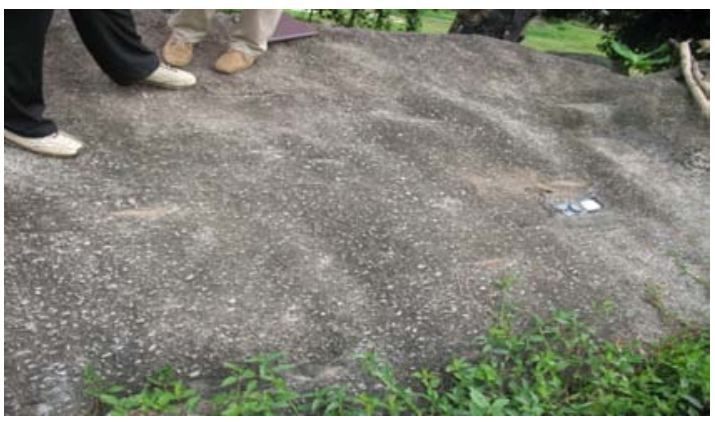

Fig. 4: Phenocrysts vary in size and orientation but some exposures show a good preferred orientation

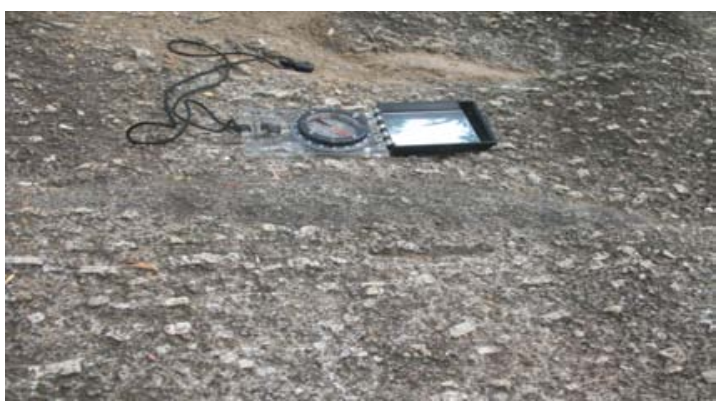

Fig. 5: Phenocrysts and Xenoliths are often in good alignment

This does not pass through the origin and also implies that when grains have zero width, they would still have a length up to 1.064 units. This is unrealistic, hence there was need to impose another straight line on the data set which passed through the origin. This second straight line has the equation $\mathrm{y}=1.617 \mathrm{x}$ and its slope $(=1.617)$ is closer to the average value of the harmonic mean as shown by Ramsay (1967) and Ghosh (1993). The 


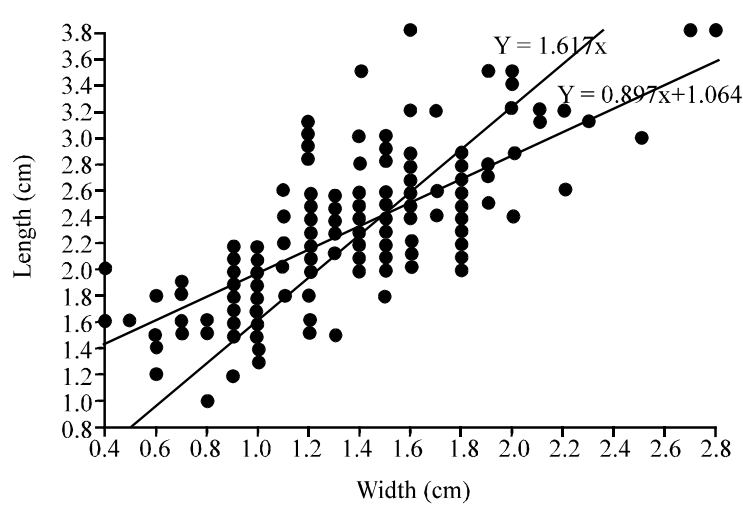

Fig. 6: Graph of length against width of phenocrysts in Uwet granodiorite

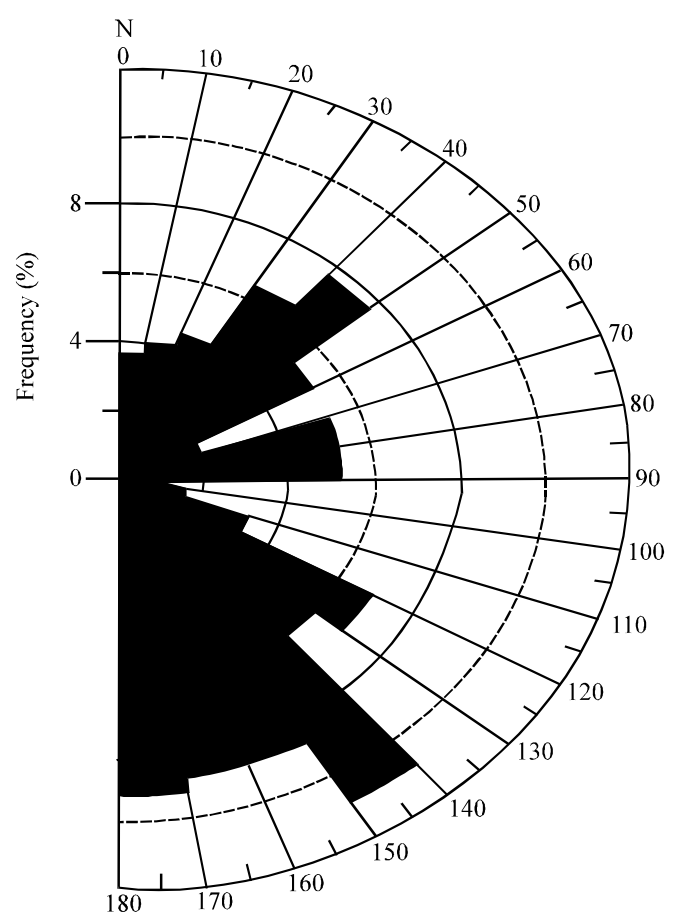

Fig. 7: Orientation rose diagram showing distribution of long axes of phenocrysts in Uwet granodiorite

orientation distribution of the long axes of the phenocrysts is shown in Fig. 7. Both the distribution table (Table 1) and the rose diagram (Fig. 7) show very strong grain orientation in the NW-SE $\left(130^{\circ}-160^{\circ}\right)$ corridor. Other directions of preferred orientation are the $\mathrm{N}-\mathrm{S}\left(160^{\circ}-180^{\circ}-\right.$ $\left.190^{\circ}\right)$ as well as the NE-SW $\left(30^{\circ}-60^{\circ}\right)$. Interestingly, the East-West corridor $\left(90^{\circ}-120^{\circ}\right)$ is the least preferred for grain orientation while the NW-SE orientation is the most preferred direction from this investigation (Fig. 7).

Only $5.64 \%$ of all the phenocrysts measured are orientated approximately in the $\mathrm{E}-\mathrm{W}$ direction while the
Table 1: Distribution of phenocrysts and strain parameters in the different sectors of orientation

\begin{tabular}{lrrrr}
\hline & Orientation & & \\
& - & & & \\
Parameters & E-W & NE-SW & NW-SE & N-S \\
\hline $\mathrm{n}$ & 14.00 & 47.00 & 64.00 & 54.00 \\
Percentage grain distribution & 5.64 & 19.00 & 26.00 & 22.00 \\
Arithmetic mean $(\overline{\mathrm{R}})$ & 1.63 & 1.69 & 1.72 & 1.78 \\
Geometric mean $(\mathrm{G})$ & 1.61 & 1.64 & 1.68 & 1.75 \\
Harmonic mean $(\mathrm{H})$ & 1.58 & 1.60 & 1.65 & 1.72 \\
\hline
\end{tabular}

N-S corridor takes about $22 \%$. The NE-SW and NW-SE orientations account for about 19 and $26 \%$, respectively (Table 1).

\section{COMPARATIVE STRAIN ANALYSIS ALONG THE AXES OF PREFERRED ORIENTATION}

The sub-total population of phenocrysts within each of the axes considered in the last section was used to determine the strain parameters, $\overline{\mathrm{R}}, \mathrm{G}$ and $\mathrm{H} . \overline{\mathrm{R}}$ which is the arithmetic mean of the ratios of long axes to short axes of the phenocrysts is given by Ramsay (1967), Lisle (1977), Ramsay and Huber (1983) and Ghosh (1993) as:

$$
\overline{\mathrm{R}}=\frac{\sum \mathrm{Rf}}{\mathrm{n}}
$$

The geometric mean $\mathrm{G}$ and harmonic mean $\mathrm{H}$ are given by the equations:

$$
\mathrm{G}=\sqrt[n]{\mathrm{Rf}_{1} \times \mathrm{Rf}_{2} \times \mathrm{Rf}_{3} \mathrm{x} \ldots \mathrm{Rf}_{\mathrm{n}}}
$$

And:

$$
\mathrm{H}=\frac{\mathrm{n}}{\sum 1 / \mathrm{Rf}}
$$

Where:

$\mathrm{Rf}=$ The ratio of long axis to short axis of a phenocryst in each equation

$\mathrm{n}=$ The population of phenocrysts in a particular orientation

Considering orientations in the E-W where $\mathrm{n}=14$, NE-SW ( $\mathrm{n}=47)$, NW-SE $(\mathrm{n}=64)$ and N-S $(\mathrm{n}=54)$, the arithmetic mean $(\bar{R})$ values calculated for these axes are $1.63,1.69,1.72$ and 1.78 , respectively (Table 1 ). G values range from 1.61 through $1.64,1.68-1.75$ while $\mathrm{H}$ values range from 1.58 through $1.60,1.65-1.72$ for the same axes referred to above. The strain in the granodiorite system has been partitioned in such a way that the maximum compression axis (E-W) showed the least grain growth with the least values of $\bar{R}, G$ and $H$ while the N-S direction where grains are in pure shear configuration shows the maximum value of the strain parameters. The simple shear axes NE-SW and NW-SE show intermediate values of strain with the NW-SE 
being the stronger of the two axes. Whether the strain partitioning produced by the phenocrysts is the same as that in the granodiorite matrix has not been proved by this research, nor is it the aim of the exercise. It is interesting to note from Table 1 that the few grains oriented closest to the maximum compression $\left(\sigma_{1}\right)$ which is approximately E-W (Ball, 1980) are those that approach equant shapes the most. Grains oriented in the general $\mathrm{N}-\mathrm{S}$ direction, on the other hand are the most oblong in shapes. Also the relationship between the calculated values of the strain parameters is of the form: $\bar{R}>\mathrm{G}>\mathrm{H}$ which was shown by Lisle (1977) and Ramsay (1967) to be the case.

\section{DISCUSSION}

Uwet granodiorite, a syn-tectonic, porphyritic granitoid shows very interesting structural features viz.: the way rigid particles rotate and orient themselves in a viscous matrix and the growth or elongation of such particles once they are favourably oriented. The NE-SW and NW-SE simple shear orientations of phenocrysts in the viscous matrix are equivalent to Ball (1980)'s and Ike (1988)'s NE-SW and NW-SE conjugate strike-slip fault system in the Pan-African mobile belt. The N-S (pure shear) trend of phenocrysts is equivalent to Ball's (op.cit.) $\mathrm{N}-\mathrm{S}$ trending vertical mylonitic shear zones where higher strains are obtained.

Since, the N-S and vertical orientations are perpendicular to $\sigma_{1}$ the maximum compressive stress-all crystallizing and recrystallizing crystals in these two orientations will according to Kamb (1959) tend to elongate fastest. But grain growth in the vertical direction (parallel to $\sigma_{2}$ direction) is prevented by the lithostatic load ( $\rho g z-P_{f}$ ) which is quite substantial (Lacomb, 2007). Hence, grain elongation in the N-S direction is partly a result of E-W compression as well as compensation for absence of growth in the vertical direction. This is probably what $\overline{\mathrm{R}}=1.78$ in the N-S orientation shows (Table 1 ). The very poor preferred orientation and grain elongation in the E-W direction add credence to Tanner and Radchiffe (1962)'s observation that the kinetics of grain initiation and growth are retarded by pressure. Also Kaufman showed that pressure retards the thermally activated processes of recovery, recrystallization and grain growth. Based on these observations, the most probable orientation of $\left(\sigma_{1}\right)$ the maximum principal compressive stress during Pan-African times is the present day $90^{\circ}-120^{\circ}$ corridor from the North, (Fig. 7). This is the corridor with the least number of grains as well as the least values of the strain parameters in the entire distribution and it occurs in the E-W orientation.
A comparison of the two simple shear trajectories: NE-SW and NW-SE (Fig. 7) shows that the latter is the stronger, both in percentage grain distribution and the $\bar{R}$, $\mathrm{G}$ and $\mathrm{H}$ factors (Table 1) than the former. This was also observed by Ike (1988) from consideration of fracture lineaments and joints in the syntectonic Zaria granite batholith of Northern Nigeria. Exactly why the NW-SE trajectory is stronger than the NE-SW is not immediately clear but it should be remembered that the distribution in question is a high temperature/high pressure one. Probably the operation of the NW-SE distribution is favoured in rocks at high temperature and pressure. That seems to be the view shown in Fig. 8 and 9. In the map area (Fig. 1) deformed meladiorite and schist are regarded as primary host rocks, the xenoliths of which are carried in the granodiorite. Small outcrops of foliated meladiorite occur in Uyanga village. Rose diagrams depicting foliation trends in Meladiorite (Fig. 8) and Schist (Fig. 9) show that the former rock type deformed in a manner that produced mainly N-S and NW-SE foliations. The NE-SW trend is either non-existent or very weak. In the schist, on the other hand, stress was transmitted by shearing predominantly in the NE-SW direction. The NW-SE trend is weak comparatively while the N-S foliation trend is nonexistent (Fig. 9). The conclusion is inevitable that shearing predominantly in the NE-SW direction was probably favoured in low temperature/low pressure media while the operation of NW-SE and N-S shears was dominant in high temperature/high pressure rocks in this pan-African

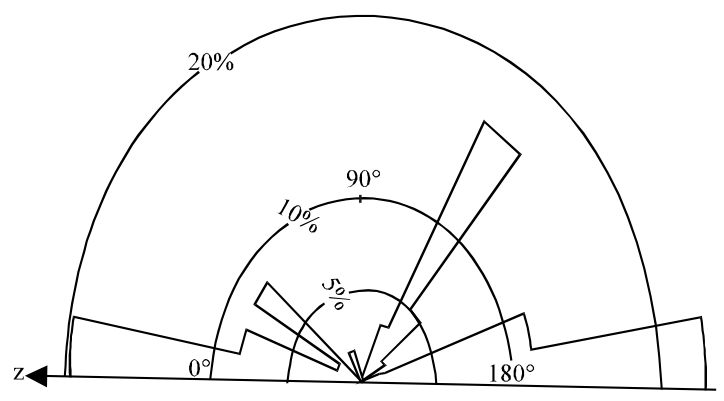

Fig. 8: Rose diagram depicting orientation of follation planes in deformed Meladiorite, Uyanga area

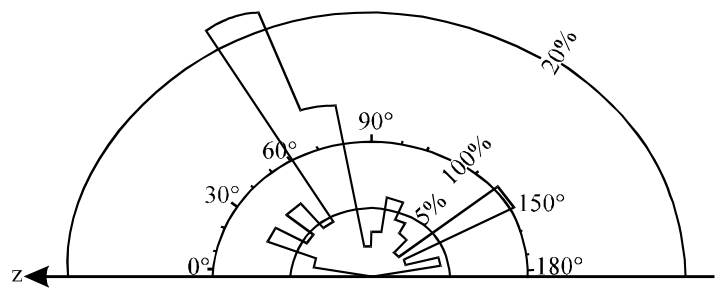

Fig. 9: Rose diagram depicting orientation of follation planes in Schist, Uyanga-Akwa Ibami area 


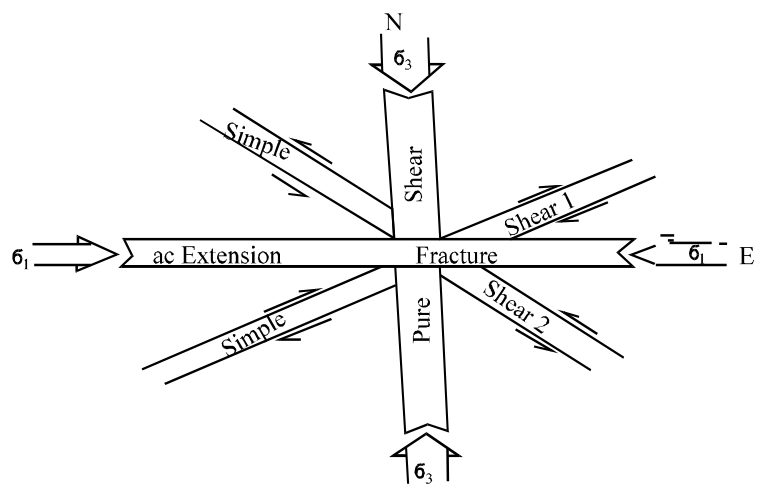

Fig. 10: The main tectonic axes of the Pan-African orogeny. $\sigma_{2}$ operated in the vertical direction perpendicular to $\sigma_{1}$ and $\sigma_{3}$. This was 5 th axis

terrain. This seems to run against the views of Ekwueme (1987) who recognized only N-S-and NE-SW trending structures as pan-African while the ENE-WSW and NW-SE trending structures he attributed to a pre-panAfrican deformation event. There was obvious lack of understanding of pan-African stress configuration in the analysis by Ekwueme (1987) which resulted in his conclusions.

A synthesis of structural orientations of pan-African origin having in mind the stress configuration that operated at that time is shown in Fig. 10. This synthesis puts together the observations of Ball (1980), Ekwueme (1987), Oluyede (1988) and Danbatta (2003) in conjunction with the findings from UyangaAkwa Ibami area.

There were five main axes by which stress was transmitted through the pan-African tectonites during deformation. The E-W axis, approximately paralleled to maximum compression was that along which ac extension fractures developed. Those high angle, E-W fractures were noticed by Oluyede (1988) to be of limited extent both in the Western and Eastern parts of the Nigerian basement complex. He also interpreted these fractures as the oldest. Similar E-W fractures have been observed near Ikot Ana (Cross River) at the western margin of Oban Massif. Some pegmatite veins are also oriented in this direction taking advantage of the existing fractures.

The NE-SW and NW-SE simple shear axes are orientations of foliations, shear fractures and faults, extension lineations, shear zones and most pegmatite veins (Ball, 1980; Oluyede, 1988; Ekwueme, 1987; Ike, 1988; Danbatta, 2003). That the NW-SE structural trend is stronger than its NE-SW equivalent has not only been shown by this research but was also reported by Ike (1988). The N-S structures developed along the pure shear axis, approximately perpendicular to the maximum principal stress $\left(\sigma_{1}\right)$. These include mineral reorientation and growth lineations, mylonitic foliations (Ball, 1980), non-mylonitic foliations (Fig. 8) (Ekwueme, 1987) as well as joints and fracture lineaments (Ike, 1988; Oluyede, 1988; Danbatta, 2003).

The fifth axis of material deformation during the Pan-African orogeny was the vertical axis. This is also the axis of intermediate principal compressive stress $\left(\sigma_{2}\right)$. The value of this stress at any level is the weight of the lithostatic load less the fluid pressure. This is a crushing and prohibitive load at the level of emplacement of the granitoid. It is for this reason that phenocrysts were not seen oriented parallel to the vertical axis in the field. All other structural trends in true Pan African tectonites (like NNE-SSW or NNW-SSE) are interpreted as those in rotational transition.

\section{CONCLUSION}

Sizeable populations of rigid objects, like feldspar megacrysts from different parts of a deformed, viscous medium can produce significant information on the strain and strain paths that operated during the deformation. Simultaneous rigid body rotations into simple shear and pure shear configurations as well as grain growth, characterized the deformation of Uwet granodiorite in its viscous/ductile states during the pan-African orogeny. From consideration of both the magnitude of the strain factors and the percentage grain distributions, it could be inferred that there were two simple shear axes and one pure shear axis operating simultaneously. The NW-SE simple shear trajectory was stronger than the NE-SW for reasons that may be related to the physical properties of the deformation. Structural studies in the Pan-African granite batholith of Kaduna-Zaria area in Northern Nigeria had indicated similar results earlier. While the NW-SE simple shear trajectory tracked the greatest number of phenocrysts, the N-S pure shear trajectory was the highest strain axis during the deformation. This combination of axes in a natural deforming rock body to share its material load and partition its strain is designed to transmit the stress imposed on it.

The N-S axis is not only a direction of strong preferred orientation but also that of greatest grain elongation in this matrix. Compared to the E-W direction, grains that initiated along or rotated into the N-S direction experienced minimum pressure-induced inhibition to growth or elongation. Those that initiated in the E-W direction experienced maximum pressure-induced retardation to growth or elongation. The corridor from $90^{\circ}-120^{\circ}$ from $\mathrm{N}$ is that with minimum grain orientation in the entire distribution and is interpreted as the maximum 
stress corridor during the Pan-African orogeny. Different parts of the granodiorite viscous matrix responded differently to stress during the period of active deformation. Hence, it is not enough to collect a large population of data only but also to sample as extensively over the intrusion as possible. Combinations of rigid rotations, plastic deformation and grain growth by diffusion could have produced the dimensional preferred orientation of and strain in feldspar phenocrysts in Uwet granodiorite at a time that the medium was very viscous or ductile.

\section{ACKNOWLEDGEMENTS}

The cooperation and assistance of the chiefs and elders of Uyanga, Akwa Ibami, Ojor Nkonemba and Iwuru communities in Western Oban Massif during the field mapping exercise is highly appreciated. Mrs. E. Oden and $\mathrm{Mr}$. V. Oden are thanked for their assistance with the preparation of the figures.

\section{REFERENCES}

Ball, E., 1980. An example of very consistent britle deformation over a wide intercontinental area: The Late Pan-African fracture system of the Tuareg and Nigeria shield. Tectonophysics, 61: 363-379.

Danbatta, U.A., 2003. The structural framework underlying the metamorphic evolution of the Kazaure schist belt, NW Nigeria. Global J. Geol. Sci., 1: 73-84.

Ekwueme, B.N. and T.N. Nganje, 2000. Geochemistry and geochronology of Uwet granodiorite, S.E. Nigeria. Global J. Pure Applied Sci., 6: 249-253.

Ekwueme, B.N., 1987. Structural orientations and Precambrian deformational episodes of Uwet area, Oban Massif, S.E. Nigeria. Precambrian Res., 34: 269-289.

Ekwueme, B.N., 1990. Rb-Sr ages and petrologic features of precambrian rocks from the Oban Massif, Southeastern Nigeria. Precambrian Res., 47: 271-286.

Ghosh, S.K. and H. Ramberg, 1976. Reorientation of inclusions by combination of pure shear and simple shear. Tectonophysics, 34: 1-70.

Ghosh, S.K., 1993. Structural Geology, Fundamentals and Modern Development. Pergamon Press, USA.

Ike, E.C., 1988. Late stage Geological phenomena in the Zaria Basement granites. A Review in the Precambrian Geology of Nigeria. Geological Survey of Nigeria: Lagos, Nigeria, pp: 83-89.

Jeffery, G.B., 1922. The motion of ellipsoidal particles immersed in a viscous fluid. Proc. R. Soc. Lond. A, 102: 161-179.
Kamb, W.B., 1959. Theory of preferred crystal orientation developed by crystallization under stress. J. Geol., 67: $153-170$.

Lacomb, O., 2007. Comparison of paleostress magnitudes from calcite twins with contemporary stress magnitudes and frictional sliding criteria in the continental crust: Mechanical implications. J. Struct. Geol., 29: 89-99.

Lisle, R.J., 1977. Estimation of the tectonic strain ratio from the mean shape of deformed elliptical markers. Geologies en Mijnbouw, 56: 40-144.

Masuda, T., K. Michibayashi and H. Ohta, 1995. Shape preferred orientation of rigid particles in a viscous matrix: Re-evaluation to determine kinematic parameters of ductile deformation. J. Struct. Geol., 17: $115-129$.

Muskhelishvili, N.I., 1953. Some basic problems of the mathematical theory of elasticity. Noordhoff, Groningen.

Odigi, M.I., 1986. Accessory minerals in the Oban Massif granitoid plutons of southeastern Nigeria-their qualitative and quantitative significance in fertility studies. J. Afri. Earth Sci., 5: 163-166.

Oluyede, P.O., 1988. Structural Trends in the Nigerian Basement Complex. In: Precambrian Geology of Nigeria, Oluyide, P.O., W.C. Mbonu, A.E. Ogezi, I.G. Egbuniwe, A.C. Ajibade and A.C. Umeji, Eds., University Press, Nigeria, pp: 93-98.

Passchier, C.W., 1987. Stable positions of rigid objects in non-coaxial flow: A study in vorticity analysis. J. Struct. Geol., 9: 679-690.

Raeburn, C., 1927. Tinstone in the calabar district. Geol. Surv. Nigeria Bull., 11: 72-88.

Rahaman, M.A., T.R. Ajayi, I. Oshin and F. Asubiojo, 1988. Trace-element Geochemistry and Geotectonic setting of Ile-Ife schist belt. Precambrian Geology of Nigeria. Geological Survey of Nigeria, pp: 241-256

Rahman, A.A.M.S., E.E. Ukpong and M. Azmatullah, 1981. Geology of parts of the Oban Massif, South-Eastern Nigeria. J. Min. Geol., 18: 60-65.

Ramsay, J.G. and M.I. Huber, 1983. The Techniques of Modern Structural Geology: Strain Analysis. Vol. 1, Academic Press, UK, ISBN: 9780125769211, Pages: 307 .

Ramsay, J.G., 1967. Folding and fracturing of rocks. McGraw-Hill, New York.

Reed, L.J. and E. Tryggvason, 1974. Preferred orientations of rigid particles in a viscous matrix deformed by pure shear and simple shear. Tectonophysics, 24: 85-98.

Tanner, L.E. and S.V. Radchiffe, 1962. Effect of hydrostatic pressure on the Kinetics of Rcrystallization in high purity copper. Acta Metallurgica, 10: 1161-1172. 